\title{
STUDYING EXECUTIVE TECHNIQUES COORDINATION NECESSITY IN IMAGING OF CHILDREN'S BOOKS WITH THE THEME OF SACRED DEFENSE
}

\author{
Maryam Fathi \\ Faculty of Arts, University of Shahed \\ barane_paeizi73@yahoo.com \\ Parviz Eghbali \\ Faculty of Arts, University of Shahed \\ eghbali@shahed.ac.ir \\ Mohsen Sadeghi \\ Russian National Academy of Sciences, Moscow
}

\begin{abstract}
:
In imaging of children's books, any of the executive practices in terms of attractiveness and effectiveness has certain types. The main objective of this research is to identify executive techniques in imaging of children's books that are generally considered in two methods including manual and computer methods in which we can see how we use them in the field of Sacred Defense. The study is based on the fundamental objective and descriptive-analytic method and the way of data collection by library resources. Studying children and the relationship between text and image are an introduction to the main topic, i.e. the analysis of these works. For a detailed review of procedures assumptions in this paper, 11 samples of imaging of children's books of illustrated books with the theme of Sacred Defense have been analyzed. At the end of this paper, for a better understanding of the theme, final result is shown in some tables. Here, the overall conclusion is that the Iranian illustrators, in their work with the theme of the Sacred Defense (between the 1980's and 2010's) used manual methods among this, watercolor technique is most widely used.
\end{abstract}

Keywords: Technique, Imaging, Children, Sacred Defense

\section{INTRODUCTION}

Techniques are apart from the images, feelings and shapes and gaining technical skills completes the theory and decomposition process. The most beautiful word that could explain the techniques is having patience and tolerance. Technique needs time, as the creative process needs time. Imager according to the story demonstrates structure, design and form of expression.

Here, the selection criteria of methodology or techniques in story visualizing are the tone of the governing space in the story and the second type is mental relationship between imagery and text and the subject of the story.

But in addition to the above discussion, now with the advent of computers to the domain of executive techniques in illustration, new discussions have been raised.

In this study, the main discussion is assessment techniques and methods used in the war-themed children's book illustration and accordingly, we can review this case and pay attention to the fact that war theme with all aspects of war on the battlefield needs what kind of image and executive techniques?

IMAGERY 
"The purpose of visualization if walls, columns and books in human history is creating more effective transition and message for communicating and creating understanding and artistic imagery in which illustrator creates illustrated narrative. "(Sayyid al-Sadr, 2004)

Illustration is a kind of verbal language or translation into the design and colors in which children interest to beauty makes better by looking at and helps to understand the concepts and content of the books makes it richer and more effective. It is a tool for the child for reading which is mixed by literary message and affects the depth of thoughts, fantasies and imaginations of children. (Ebrahimi, 1988)

Images of a book not only give beauty, but also must reflect the image with meaning and full of content. The book artist either to paint for illustrated book or books that have not lots of images, however, for a better understanding of the text and the subject of the story, must help the child.

The artist must rehabilitate worthwhile scenes and ideas in the story. Each image must be equal to one of the opinions expressed in the text. Images encourage reader to rule to apply his/her imagination rule and go ahead the story. This is one of the main purposes of illustration, because awakening and strengthening the imagination is one of the main causes of mental development of children. Illustrator must create the image that makes the image for audience to think about story elements which are mentioned in the text.

$\mathrm{He} / \mathrm{she}$ should provide images with enough detail to help as a guide on the subject of the story. (Golduzian, 2005)

\section{ANALOG ILLUSTRATION}

The purpose of Analog illustration is presenting works that are done solely by hand without the aid of computers. This type of visualization includes a variety of visualization techniques such as watercolor, gouache, collage, printing, scratch board and so on. In this method of illustration, just in the process of scanning and printing, it is out of the domain of activity of the artist.

\section{COMPUTER (DIGITAL) ILLUSTRATION}

Digital imaging are also addressed to all processes creating images through 0 and 1 (computer language), albeit it can be seen here in two different views. First, someone believes that digital imaging describes any product obtained by a picture from the computer. Mr. Farshid Mesghali says: My understanding from the digital illustration is that computer tool is 0 and 1, and any matter with this tool is a digital production.

In fact, according to this group, if the work is done on the computer and the product anything, even if is attainable with other ways and means, is also called open digital.

\section{TECHNIQUE}

Technique is word that is usually used in English and French to show the appearance of any work of art which is employed and is synonymous with the word "Skill" in Arabic and "Art" in Persian. The word comes from the Greek root of the word "techno" is usually applied to two meanings.

In a sense is the skill to create everything with the power and other means is to identify and know.

In the second case, "techno"1 creates something that the Greek philosophers called it as "poesies" ${ }^{2}$ that in fact is the tangible expression of a subtle affair. This is how the science and knowledge in general and knowledge in the most general sense, i.e. to see and to visit it. 
At this point, the nature of knowing is the unveiling of the creatures and objects, i.e. with techno or technique everything becomes visible and manifest and obvious.

\section{THE IMPACT OF TECHNIQUE AND TOOL ON THE CONCEPT OF VISUALIZATION}

The proper use of executive tool and techniques is one of the imager's skills, so with an understanding of visual effects of tools, be able illustrate the desired feeling or concept better and each tool has some characteristics that as using it for creating illustrations, these features affect the concept.

\section{RELATIONSHIP BETWEEN THEME AND TECHNIQUE OF THE BOOK ILLUSTRATION} In choosing this topic for illustrated books, it should be noted that readers of books are in which age group and should illustrate the issue with the use of convenient and attractive technique according to their psychological needs.

In illustration of the book, if the story topic is not associated with the appropriate technique, it cannot have a good effect on the psyche of children and young people. The concept of a story will be achieved once technique is on the subject and called it "sit" and a close relationship between the two is created.

Personal attitude of imager along with skills and capabilities of illustrator is seen as the viewing angle to explore and examine the matter or subject as the most appropriate point of view. Pictures of books, thoughts and feelings are expressed through the effective application of imaging techniques with the appropriate language.

Illustrator has a wide range of tools, but is often the subject of book that is the determining factor in the use of appropriate technique for creating images, as well as the method of choosing techniques depends on the child's children's book illustration. Understanding the kind of thinking and mindset and the best way to understand the basics of choosing the right technique of illustration for children is knowledge of the world of the child.

As the range of technique spread in book illustrations, new awareness of technique and usability to use it in a variety of subjects for Illustrations is achieved.

\section{TOOL IN ILLUSTRATING BOOKS FOR CHILDREN}

Picture $s$ a kind of illustrated, thought and feeling language expressed through effective use of technology in graphics and painting.

His/her training and skills are assessed in terms of how to use these tools in order to demonstrate his/her understanding of the function of the form, psychological sensitivity, originality and selfcontrolling of tools. All these powers are determined in the images he/she creates for picture of books. Illustrator may use two or three tools in any work and sometimes just a tool. Illustrator expressed about the quality of their search and according to the topic, selects appropriate view of the tools.

In selecting the image tool, several cases must be considered:

1) Subject: (what type of tool can better express the issue)

2) Field of work: (every tool cannot be applied at the current field)

3 ) The title and power of imager in employing a variety of tools

It is also a critical issue that some illustrators are fluent on only special tools. Someone works with color, someone with pencil and someone with Rapid. Since we said that there is a relationship between subject and tool, now with respect to the subject that requires special tools, if it is not be possible to use such a tool, what should we do?

Some of the artists to create visual images can work with various art media and are not bound to a specific method. 
The story mode is the determining factor of the painter and he/she must believe that no other tools are effective for expressing that story except the selected one. He/she must use unique features of that tool and should be able to present what the mediators adequately meet through art with the best conditions "(Royesh, 1993).

\section{Technique in the illustration of children's books}

Nowadays, the technique will also be presented with this concept that "technique is the personal method to use the tools and how they work and how to choose the material in creating a work of art. So factor that brings art to the pure creativity is artistic individual character in the way of personal expression and how methods and techniques are employed "(Nami, 1987)

Artist through the use of special techniques appropriate to the subject and content of his/her work, established mental relationship with the audience and thereby transfers the message to her/him. An important part of art alphabet is "technique" which the artist speaks to us through that and lead to unknown world of ideas and imagination in the mind.

Before starting work, the illustrator should have certain about techniques matched with the theme of your work, so important factor in creating a work of art is the method used is in it in which many art critics believe that fifty percent of the value of a work depends on the technique.

Thus, in order to see how best to use the tools and instruments as well as to the most appropriate use of materials, we should identify various functions of these elements and employ them due to the theme of the content of the work.

In the study of books, we found that many of the techniques have weakened the image, because many different types of tool are used in a way that not only we have not a pretty picture but also nasty and dull.

Face color scheme and the specific characteristics and implications created in children by observing, is not applicable with any technique.

In fact, illustrator in his/her technique must consider three bases of time, location and the matter. What techniques can better show the light of day, night darkness, past era and present or future spaces or what technique can show scare of elephants, goats, soft sable of fur, mane and varnish lines of leopard and lion, scales of snake and fish?

In a brief look at the pictures in children's books, often we find that illustrators, more or less, care the relationship between the three axes (time, place and topic) along with the techniques employed in the work.

"In fact, visualization is not done not only by drawing and painting tools, but nowadays, designers and illustrators in any way use expressive features and visual art for portraying their subject." (Nami, 1987)

Using computer in imaging system has been very strong. However, in reviewing the books, we face items like letters and assembly and changing the color and hundred percent run picture by computer is not found, but due to sophisticated computer facilities, it is feasible and possible.

"How much computer programs can have an effect on the share of illustration and assist him/her or even replace or with the help of an application that has already been given, as the order of the illustrator or publisher, build a picture for the book contexts? (This is a question that Illustrator should note on the PC usage) (bimonthly print magazine, 1993) 


\section{The relationship between text and image}

"In fact, the children's book text is a field of children's lives. Text can familiarize children with another world and other people (even when all faces are turned into animals) and will take him/her to the audience and through this, the mind becomes strengthened, fulfill the emotional needs as well as opened the mouth to speak to another and display literature, culture and traditions and legends of the community against him/her. "(Sohrab (Mafi), 1993)

The relationship between text and image is the sustainable feature of imagery and imager in addition of having independence in showing image, imager is required to follow the text in text speak. In this regard, also consider child's understanding criteria in employing the technique and personal fantasies.

"Harmony and balancing the image with the text in terms of facial conditions (associated with the image and text) and spiritually (fitness and interconnectedness between image and text) should be considered by imager." (Hodayi, 1989)

Children's book illustrator should not move out of context, because will fail the main purpose of the book that is being read.

Thus, images must help in an appropriate way to transfer the message of writer well and of course, this does not mean that the character of illustrator is ignored or writer or is placed in service, but it makes that the ability and talent of Illustrator are used along with creative power and due to his/her interest, select a special genre for Illustrations and can illustrate with any style or genre that loves and with any tool that wants for the story (Siansiolo, 2001).

\section{The relationship between form and content in illustration}

Illustration means showing the meaning and qualitative terms. But the "form" meaning "image" can never show the quality immediately. Then for better expressing qualitative terms, the "image" should be translated to sign of a "little bit" mark. In this definition, intangible factors governing the story through image are converted to quite tangible and objective factors and acted upon, the first task in the imaging is paying attention to the " visual expression capabilities," which is how far been able to bring the story or topic.

Certainly, illustrator, before anything, should care intangible factors in writing and this is a commitment that exists fundamentally in the illustration. "Commitment» to the text's content and theme of the work is the base of art imagery. On the other hand, we cannot ignore the role of "tangibles" factors. These factors show the image structure of a text through "techniques".

\section{Imagery and concepts related to war}

War, in addition to bringing great destruction, causes many changes in the culture and art of the time. In a society where war happens, art in the community is affected by the war and pen along with the gun puts a foot into battle and sometimes creates epics that can be more effective than any weapon in the war.

The close relationship between art and war in the communities we face war. Influencing artists such as Picasso and earlier Gouya with the war effects and clearer of all, the Iran-Iraq war and influence of Iran's painters direct all expressing eloquent in this respect.

But the impact of war on art will once more be made as assault against the values of a nation occurs and in fact, the cultural and ideological defense occurs. And the eight years of sacred defense also include the great themes of sacrifice, martyrdom and heroism in which nowadays in regret of having such concepts. So this great task is under the responsibility of artists who are committed for art messaging. 
Since the 1980's, Iran faces the war as a social phenomenon that raised new issues and concepts and children whose fathers were away from them or forever away, or lost their homes and their lives and other problems that the war imposed on the community.

"War. Name (Fatah J) battle, war, fighting and the battle between some people or the forces of two countries "(Mire mad)

The phenomenon of conflict is an issue that since the beginning of human civilization is along with human beings sometimes battle to earn more points and sometimes for that the enemy is obligates to follow his own goal.

$1.68 \%$ of the story books are about the Holy Defense issues and in fact, stories about the war is limited and there are a number of children's books of poetry and painting published about the war.

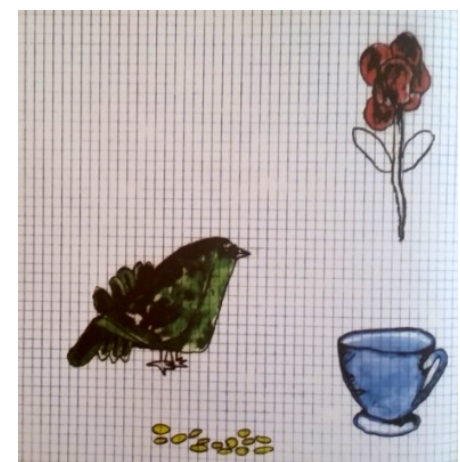

Figure1. I have seven days per a week, Mohammad Reza Dadgar

According to visualizing concepts in stories that directly or indirectly has raised the war we investigate the imagery of the relevant concepts, such as parental separation grief, testimony and war.

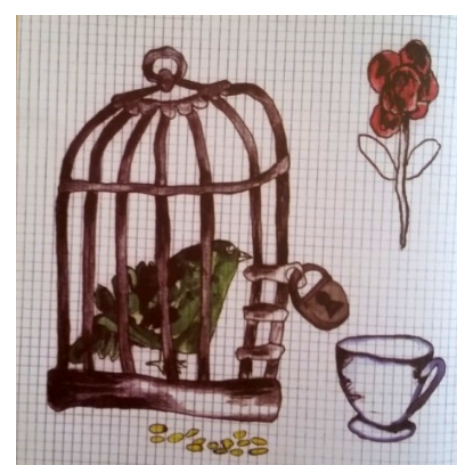

Figure2. I have seven days per a week, Mohammad Reza Dadgar

In this work, being away from his father and the grief of that is illustrated in an abstract super simple story, yet smooth with pleasant and simple paintings, smooth and with nice paintings and illustrations. Dadgar with the prettiest and easiest way, illustrate the little girl sadness, of course, a good text has a considerable role in achieving this success. In the absence of a father, a bird is in the cage, do not eat water and seeds and in his presence, bird is released.

War stories are usually illustrated indirectly in these concepts such as "curly hair", Illustrator: Taghavi (1985); O Ibrahim, Illustrator: Khaef, (1985); Khandaneh, Mohammad Reza Yousefi, Illustrator: Shahdadi.

In the book "O Ibrahim" which has a fascinating story, Ibrahim is an old shoemaker in a city at the front line of war and with sacrifice, repairs the fighter's shoes and eventually becomes martyr at the 
bombing. Image provided from his testimony with colors close to brown, while he landed shows the death and not testify. (Figure 3)

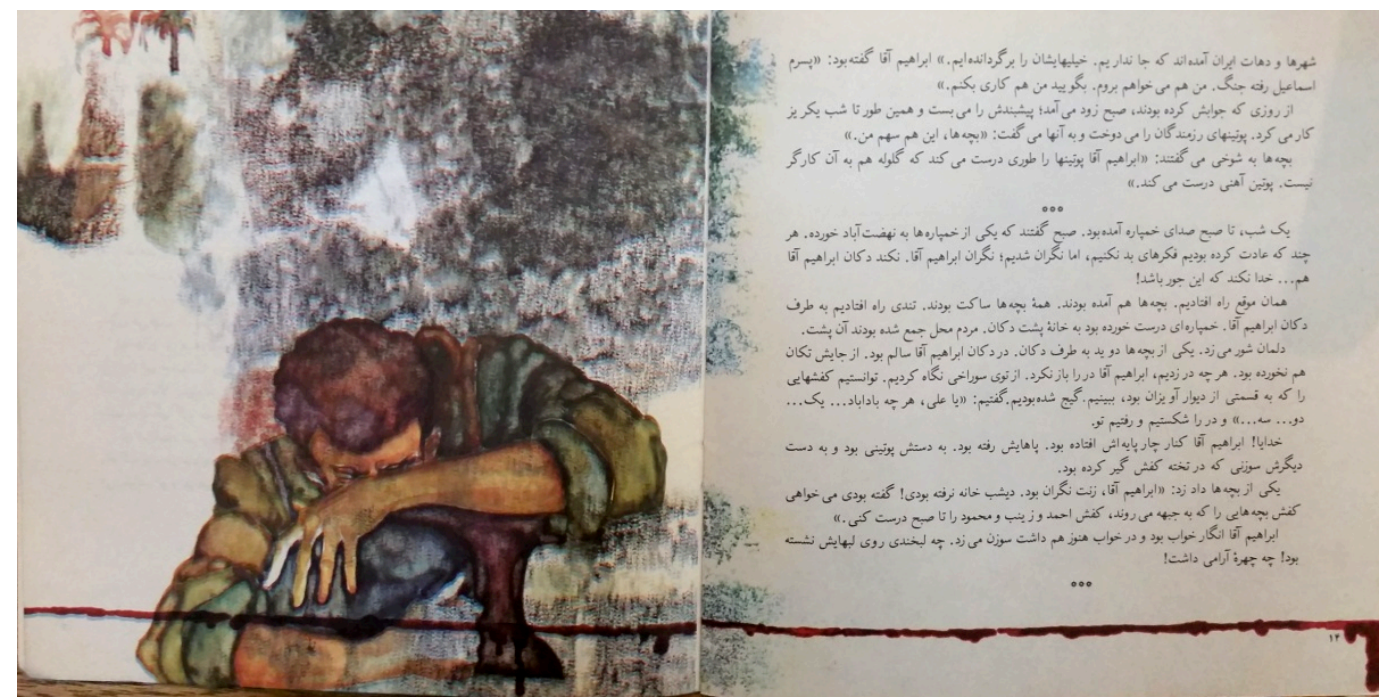

Figure3. O Ibrahim, Illustrator: Khaef

\section{LITERATURE REVIEW \\ WITNESS}

Contrary to what in the West in recent decades is advertised and applied as little as possible, our stories of the sacred defense for the children and youth, do not include a lot of events and scenes of disasters and incidents of violence.

In a considerable part of these stories, we see testimony or injury of a family member, relatives, friend or related person to the children and adolescents or the population of a region in the story. In a batch of these stories, the child or adolescent is hero and becomes martyr as a result of enemy air strike or during a battle in the battlefield. One of the most striking and most documented examples of this is Hussein Fahmideh, a thirteen year old teenager who by taking grenades at his waist and throwing himself under the enemy tank created a fantastic epic and becomes famous for everyone. The greatness of his work so much that Imam Khomeini told him leader of himself and the others (Sarshar (Rahgozar), 225, 2002-227)

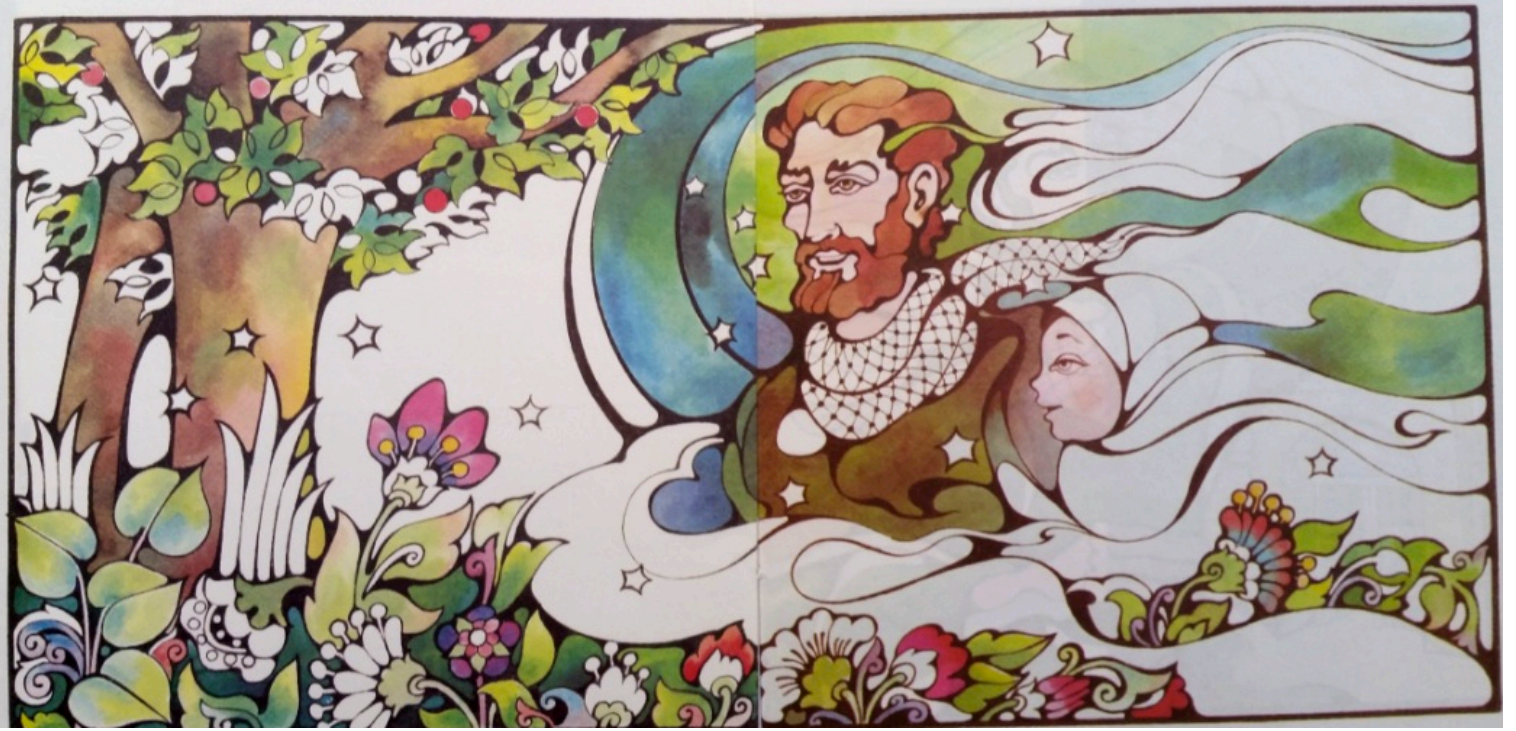

Figure4. Thirteen-year-old leader- Hadith Nineveh computer unit

\section{VETERANS}


One of the most striking issues and consequences of war is the subject of veterans. So that if a lot of problems and the debris of war are ended during the years or eliminated and forgotten, symptoms and physical and psychological consequences of injury are raised, because the children are much less face war and battle with the enemy and naturally, the number of stories of this kind and the child or adolescent heroes. Instead, we see the stories whose heroes in the air strikes, missiles or artillery enemy to residential areas are disabled and out of order. While in a bunch of these stories, the veteran character is the father or an older member of the family.

In Sacred Defense literature for children and teenagers, this issue is usually manifested in four forms:

1) Veteran of child or adolescent hero due to the bombardment of the area and his location and residence in the back or within the case

2) Disability of father and someone close to teenage in the case and its impact on his life and his family

3) In the third kind of this kind of works, the protagonist or his close relatives are not veterans. But because they feel that they are not able to do important work to help the Sacred Defense stream, decided that by doing service for a veteran pay their liability to them.

4) In the fourth type, a veteran, with the conduct and behavior, affected people and will change him.

It is natural that the main theme of the first and second of these stories is how the child or adolescent adapt with different stages of coping with the new situation emerged due to their disabilities for himself and his father or ..., or probably how to overcome weaknesses and problems by the relatives of veteran and to minimize the negative impacts of this situation on family life and their professional routine. (Sarshar (Rahgozar), 234, 2002-233) (Figure 5)

Figure5. Like Dad's eyes - Parviz Eghbali

\section{FREEDOM}

Until the last years of the war, especially in terms of the people who lived in the far away from the field of battle, and some had never seen war closely, capturing by the enemy was absurd and perhaps counter-value. In the war line, for many years, the general trend was the same. So that, a number of our fighters prefer to either kill or be killed and they prefer testimony rather than the bondage to the enemy.

In other words, they consider capturing as disgrace for themselves. For the same reason, we have seen that at the end of war, the total number of about Iraqi POWs was 57/000, but Iranian POWs was 39/000. While we know that until the end of the eight-year Sacred Defense, Iran's population was about three times the population of Iraq and our side, due to world's total arms embargo for the Islamic Republic of Iran, as well as the enthusiasm of our faithful people to participate in the defense of the country, relied far more on human resources.

In this way, and naturally, a number of Iranian forces caught in the grip of Iraq should be two to three times more than Iraqi prisoners. But we saw that it is not done.

In other words, if for no other reason over faith, courage and self-sacrifice of the Iranian forces, and their belief to the right way looking for, also, their hatred of the aggressor, corrupt and bloodthirsty ruler regime of Iraq did not exist, by the brief view to the official statistics, clearly, this issue is shown and proved. Meanwhile, another reason for the Iraqis military tendency to being captured by the Persians was the good and human Islamic manner of our warriors with enemy POWs. (Sarshar (Rahgozar), 246, 2002-245). (Figure6) 


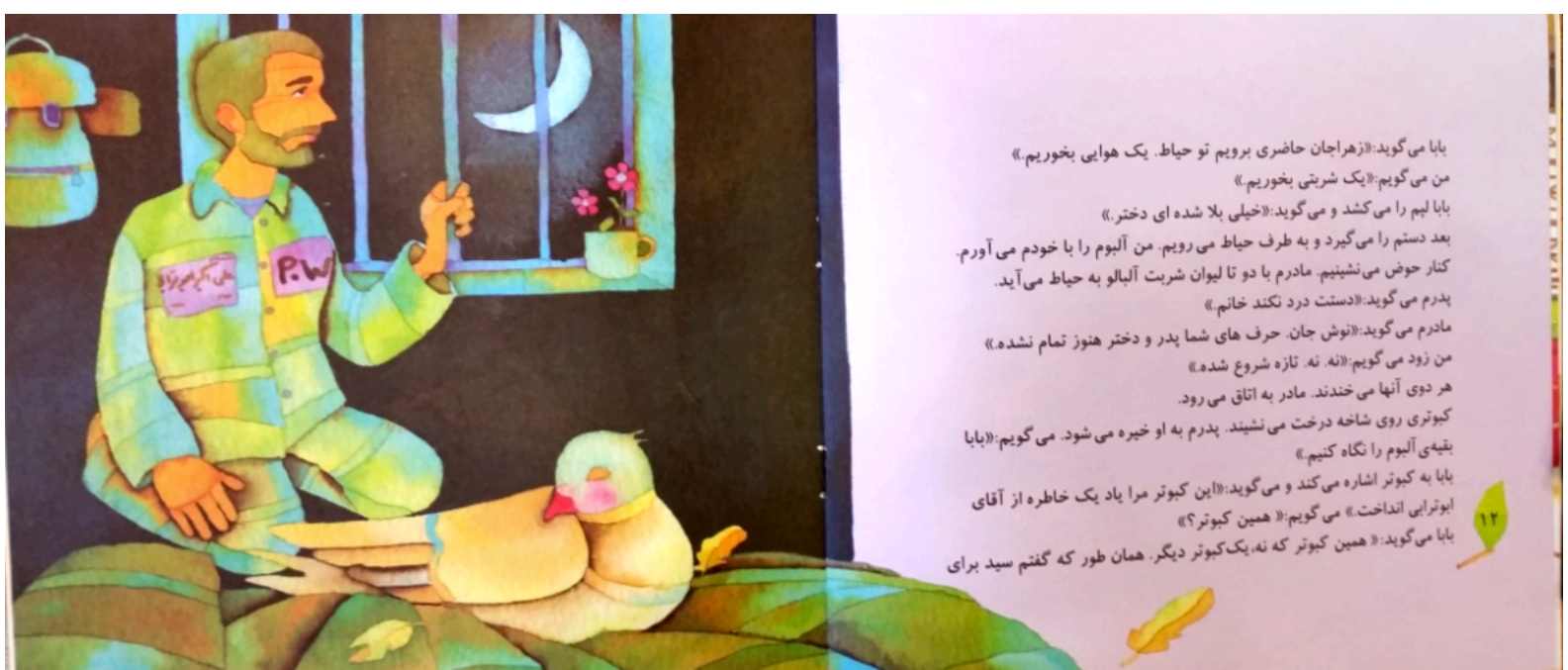

Figure6. Guest from the sky, Somayeh Bighdeli

\section{STORIES WITH GIRL HERO}

Iranian girls, especially from a young age find less realistic picture of them in the literature. This is a big failure and has caused concern; And perhaps one of the most important factors for early adoption and of course damaging of our teenage girls to adult fiction is the same shortcomings. This issue that what are the causes is an independent discussion. If the holy defense stories are often related to boys, it suffers one-dimensional aspect and perhaps the most important causes are the same reasons that make problems for all children's literature. But besides that, fictions of war in other countries have faith and culture different situations with us referring one to one and armed conflict entered spontaneously and inevitably leading male character. Since a significant part in the holy war stories for children and adolescents is related to combat operations, boyhood (read masculinity aspect) in this branch of the literature, inevitably, has been more pronounced. Sarshar (Rahgozar), 331, 2002-333). (Figure 7)

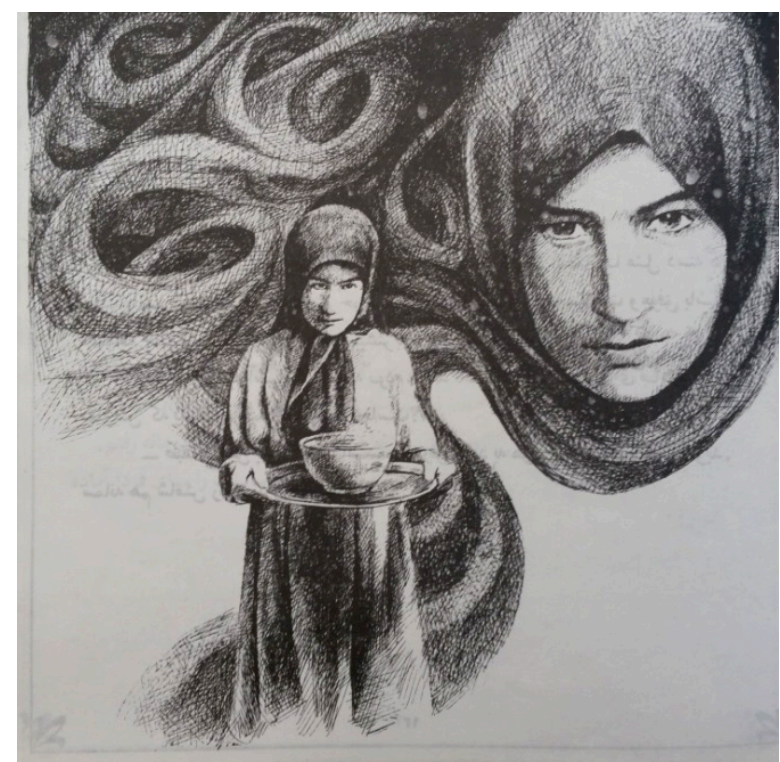

Figure7. With little heart of my mother, Parviz Eghbali, technique of metal pen

\section{FAMILY IN THE ABSENCE OF THE FATHER}

The absence of the father from the home and family, to attend the fronts of war, or perhaps testimony or his captivity in this way created economic and psychological problems especially for the survivors that sometimes large and deep. Sarshar (Rahgozar), 305, 2002). (Figure8). 


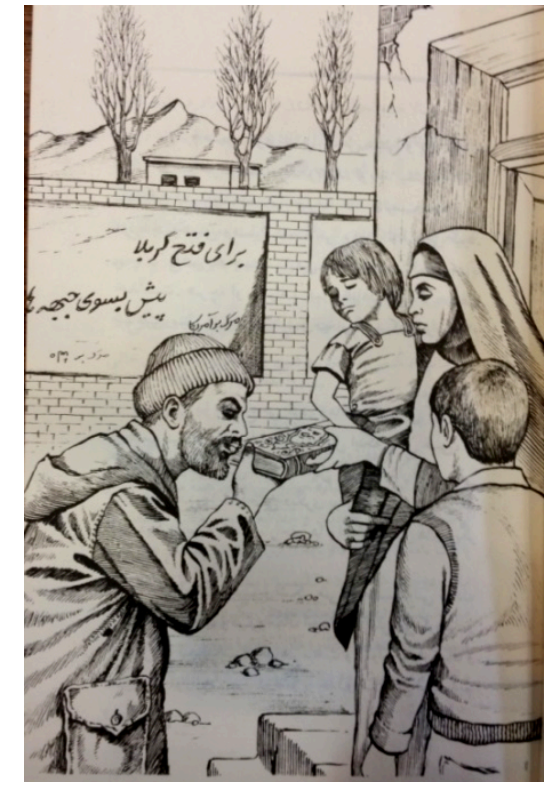

Figure8. Pending for testimony, Sadegh Sandoghi, technique of metal pen

REVIEWING CHILDREN'S BOOKS SUBJECTS WITH HOLY DEFENSE TOPIC BETWEEN THE DECADES OF 1980S TO 2010S IN IRAN

\begin{tabular}{|c|c|c|c|c|c|c|c|c|c|c|c|c|c|c|c|c|c|c|c|c|c|c|c|}
\hline \multicolumn{12}{|c|}{ Work theme } & \multicolumn{12}{|c|}{ Executive technique } \\
\hline \multicolumn{2}{|c|}{ 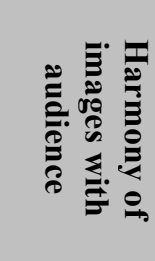 } & \multicolumn{2}{|c|}{ 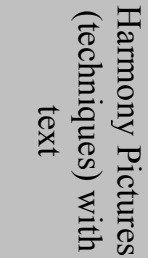 } & \multirow{2}{*}{ 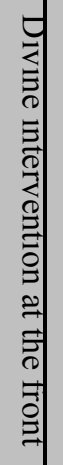 } & \multirow{2}{*}{ 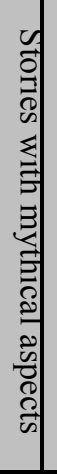 } & \multirow{2}{*}{ 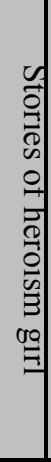 } & \multirow{2}{*}{ 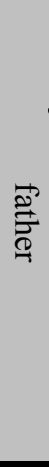 } & \multirow{2}{*}{ 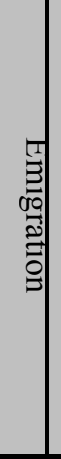 } & \multirow{2}{*}{$\begin{array}{l}T \\
\overrightarrow{0} \\
0 \\
0 \\
\stackrel{0}{0} \\
0\end{array}$} & \multirow{2}{*}{ 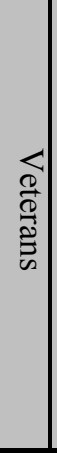 } & \multirow{2}{*}{ 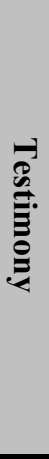 } & \multirow{2}{*}{ 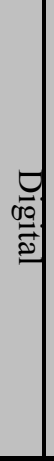 } & \multirow{2}{*}{$\begin{array}{l}\text { 固 } \\
\text { : } \\
\text { : } \\
\text { : }\end{array}$} & \multirow{2}{*}{$\begin{array}{c}\Omega \\
\stackrel{\bar{\vartheta}}{0} \\
09 \\
0\end{array}$} & \multirow{2}{*}{ 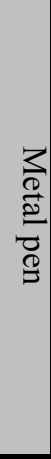 } & \multirow{2}{*}{ 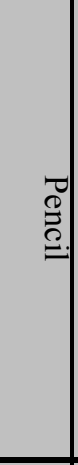 } & \multirow{2}{*}{ 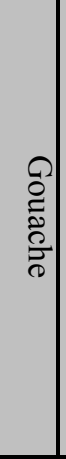 } & \multirow[t]{2}{*}{$\Xi$} & \multirow{2}{*}{ 궁 } & \multirow{2}{*}{ 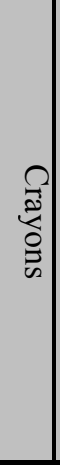 } & \multirow{2}{*}{ 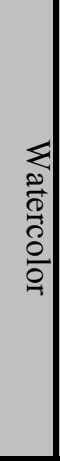 } & \multirow[t]{2}{*}{$\begin{array}{c}\text { The } \\
\text { book's } \\
\text { title }\end{array}$} & \multirow[t]{2}{*}{$\pi$} \\
\hline $\begin{array}{l}\text { W } \\
\text { it } \\
\text { h } \\
\text { o } \\
\text { ut } \\
\end{array}$ & $\begin{array}{c}\text { Wit } \\
\mathrm{h}\end{array}$ & $\begin{array}{l}\text { Wi } \\
\text { th } \\
\text { ou } \\
t\end{array}$ & $\begin{array}{l}\mathrm{Wi} \\
\text { th }\end{array}$ & & & & & & & & & & & & & & & & & & & & \\
\hline & $*$ & & $*$ & & & $*$ & & & & $*$ & & & & & $*$ & & & & $*$ & & $*$ & $\begin{array}{c}\text { Like } \\
\text { Dad's } \\
\text { eyes }\end{array}$ & 1 \\
\hline \multirow[t]{3}{*}{$*$} & & & $*$ & & & $*$ & $*$ & & & & & & & & $*$ & & & & & & $*$ & $\begin{array}{c}\text { I have } \\
\text { seven } \\
\text { days per } \\
\text { a week. }\end{array}$ & 2 \\
\hline & $*$ & & $*$ & & & $*$ & & & & & & & $*$ & & & & $*$ & & & & $*$ & $\begin{array}{c}\text { Khandan } \\
\text { eh }\end{array}$ & 3 \\
\hline & $*$ & & $*$ & & & & $*$ & & & & $*$ & & & & $*$ & $*$ & & & $*$ & $*$ & $*$ & $\begin{array}{c}\text { Goodbye } \\
\text { father }\end{array}$ & 4 \\
\hline \multirow[t]{4}{*}{$*$} & & $*$ & & & & & & & & & $*$ & $*$ & & & & & & & & & & $\begin{array}{l}\text { Thirteen- } \\
\text { year-old } \\
\text { leader }\end{array}$ & 5 \\
\hline & $*$ & & $*$ & & $*$ & $*$ & & $*$ & & & & & & & & & & & $*$ & & $*$ & $\begin{array}{c}\text { Curly } \\
\text { Hair }\end{array}$ & 6 \\
\hline & $*$ & & $*$ & & & & & & $*$ & & & $*$ & & & & & & & & & & $\begin{array}{c}\text { Guest } \\
\text { from the } \\
\text { sky }\end{array}$ & 7 \\
\hline & $*$ & & $*$ & & & & $*$ & & & & $*$ & & & & $*$ & & & & & & & Waiting & 8 \\
\hline
\end{tabular}




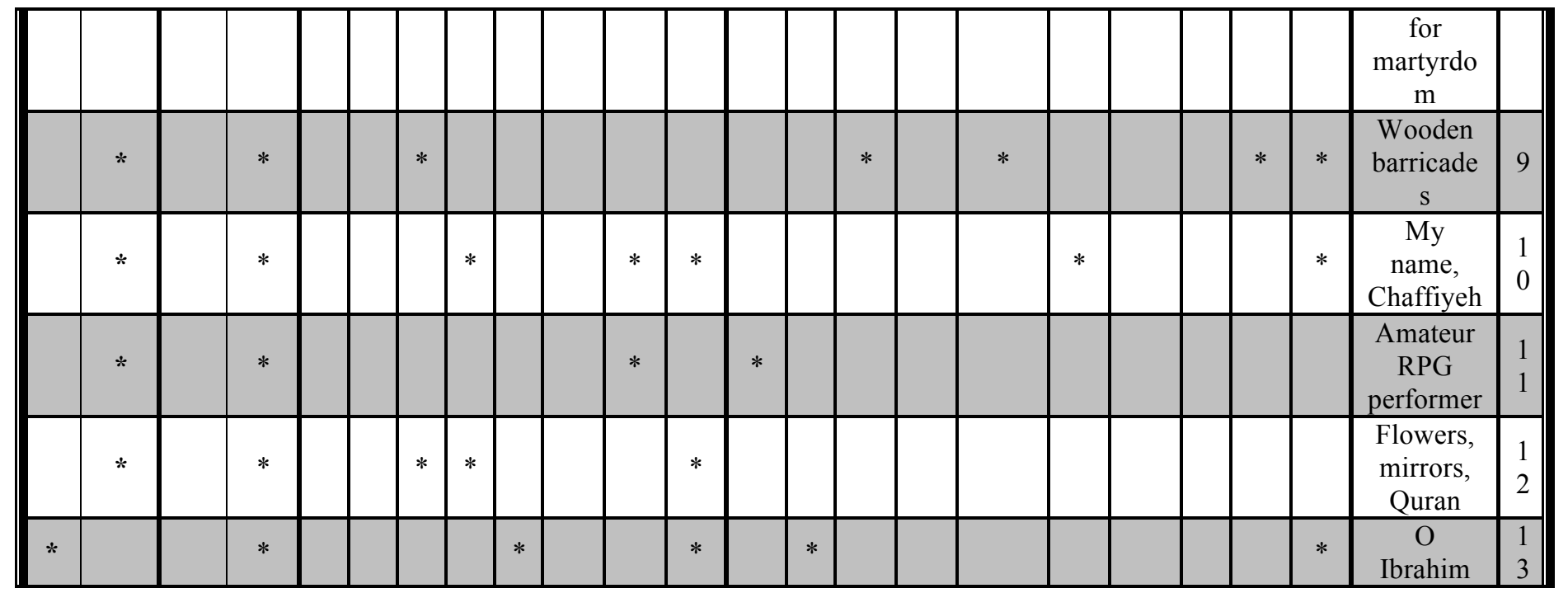

\section{REVIEWING CHILDREN'S BOOKS SUBJECTS WITH HOLY DEFENSE TOPIC BETWEEN THE DECADES OF 1980S TO 2010S IN IRAN}

\begin{tabular}{|c|c|c|c|c|c|c|c|c|c|c|c|c|c|c|c|}
\hline 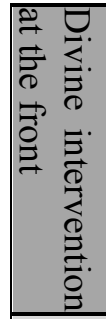 & 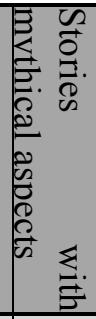 & 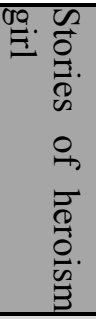 & 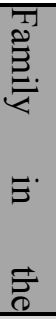 & 率. & 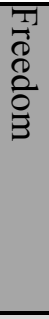 & $\begin{array}{l}\frac{1}{0} \\
\frac{1}{1} \\
\frac{1}{0} \\
\vdots \\
0 \\
0\end{array}$ & 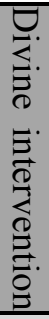 & $\begin{array}{l}Z \\
Z \\
\Xi \\
3 \\
0 \\
0 \\
0 \\
0 \\
\rightarrow \\
0 \\
0 \\
0 \\
0 \\
0 \\
0\end{array}$ & 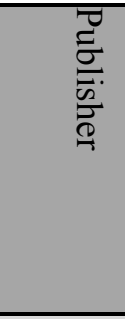 & 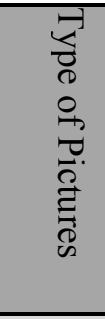 & 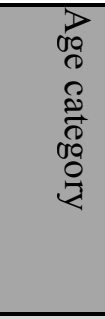 & $\begin{array}{l}\text { Illustrat } \\
\text { or }\end{array}$ & Writer & $\begin{array}{l}\text { Name } \\
\text { of the } \\
\text { book }\end{array}$ & ְֶ \\
\hline & & & $*$ & & & * & & 27 & $\begin{array}{l}\text { Institu } \\
\text { te for } \\
\text { the } \\
\text { Intelle } \\
\text { ctual } \\
\text { Devel } \\
\text { opme } \\
\text { nt of } \\
\text { Childr } \\
\text { en and } \\
\text { Youn } \\
\text { g } \\
\text { Adults }\end{array}$ & $\begin{array}{r}\text { Color } \\
\text { ed }\end{array}$ & "D" & $\begin{array}{l}\text { Parviz } \\
\text { Eghbali }\end{array}$ & $\begin{array}{l}\text { Razieh } \\
\text { Dehghan } \\
\text { Salmasi }\end{array}$ & $\begin{array}{l}\text { Like } \\
\text { Dad's } \\
\text { eyes }\end{array}$ & 1 \\
\hline & & $*$ & $*$ & & & & & 18 & $\begin{array}{l}\text { Institu } \\
\text { te for } \\
\text { the } \\
\text { Intelle } \\
\text { ctual } \\
\text { Devel } \\
\text { opme } \\
\text { nt of } \\
\text { Childr } \\
\text { en and } \\
\text { Youn } \\
\text { g } \\
\text { Adults }\end{array}$ & $\begin{array}{r}\text { Color } \\
\text { ed }\end{array}$ & $\begin{array}{l}\text { "A", } \\
\text { "B" }\end{array}$ & $\begin{array}{l}\text { Moham } \\
\text { madrez } \\
\text { a } \\
\text { Dadgar }\end{array}$ & $\begin{array}{l}\text { Ahmad } \\
\text { Reza } \\
\text { Ahmadi }\end{array}$ & $\begin{array}{l}\text { I have } \\
\text { seven } \\
\text { days per } \\
\text { a week. }\end{array}$ & 2 \\
\hline
\end{tabular}




\begin{tabular}{|c|c|c|c|c|c|c|c|c|c|c|c|c|c|c|c|}
\hline & & $*$ & & & & & & 27 & $\begin{array}{l}\text { Sunsh } \\
\text { ine } \\
\text { House }\end{array}$ & $\begin{array}{r}\text { Color } \\
\text { ed }\end{array}$ & $\begin{array}{l}\text { "C", } \\
\text { "D" }\end{array}$ & $\begin{array}{l}\text { Nafisa } \\
\text { Shahda } \\
\text { di }\end{array}$ & $\begin{array}{l}\text { Mohamm } \\
\text { ad Reza } \\
\text { Yousefi }\end{array}$ & $\begin{array}{l}\text { Khanda } \\
\text { neh }\end{array}$ & 3 \\
\hline & & & $*$ & & & & $*$ & & $\begin{array}{l}\text { Keiha } \\
\mathrm{n} \\
\text { Publis } \\
\text { hing }\end{array}$ & $\begin{array}{r}\text { Color } \\
\text { ed }\end{array}$ & "C" & $\begin{array}{l}\text { Parviz } \\
\text { Eghbali } \\
\text { Kali } \\
\text { Khoday } \\
\text { i }\end{array}$ & $\begin{array}{l}\text { Naser } \\
\text { Naderi }\end{array}$ & $\begin{array}{l}\text { Goodby } \\
\text { e father }\end{array}$ & 4 \\
\hline & & & & & & & $*$ & 11 & $\begin{array}{l}\text { Hadit } \\
\mathrm{h} \\
\text { Ninev } \\
\text { eh } \\
\text { public } \\
\text { ation }\end{array}$ & $\begin{array}{r}\text { Color } \\
\text { ed }\end{array}$ & $\begin{array}{l}\text { "B", } \\
\text { "C" }\end{array}$ & $\begin{array}{l}\text { Hadith } \\
\text { Nineve } \\
\text { h } \\
\text { publicat } \\
\text { ions } \\
\text { comput } \\
\text { er unit }\end{array}$ & $\begin{array}{l}\text { Mehdi } \\
\text { Vahidi } \\
\text { Sadr }\end{array}$ & $\begin{array}{l}\text { Thirteen } \\
\text {-year- } \\
\text { old } \\
\text { leader }\end{array}$ & 5 \\
\hline & $*$ & $*$ & & $*$ & & & & 23 & $\begin{array}{l}\text { Shoko } \\
\text { ofeh } \\
\text { Books }\end{array}$ & $\begin{array}{r}\text { Color } \\
\text { ed }\end{array}$ & "C" & $\begin{array}{l}\text { Nayere } \\
\mathrm{h} \\
\text { Taghavi }\end{array}$ & $\begin{array}{l}\text { Shahla } \\
\text { Barforoos } \\
\text { h }\end{array}$ & $\begin{array}{l}\text { Curly } \\
\text { Hair }\end{array}$ & 6 \\
\hline & & & & & $*$ & & & 16 & $\begin{array}{l}\text { Paya } \\
\text { m } \\
\text { Azade } \\
\text { gan } \\
\text { public } \\
\text { ation }\end{array}$ & $\begin{array}{r}\text { Color } \\
\text { ed }\end{array}$ & $\begin{array}{l}\text { "B", } \\
\text { "C" }\end{array}$ & $\begin{array}{l}\text { Somaye } \\
\mathrm{h} \\
\text { Bighdel } \\
\mathrm{i}\end{array}$ & $\begin{array}{l}\text { Saeed } \\
\text { Askari }\end{array}$ & $\begin{array}{l}\text { Guest } \\
\text { from the } \\
\text { sky }\end{array}$ & 7 \\
\hline & & & $*$ & & & & $*$ & 80 & $\begin{array}{l}\text { Mous } \\
\text { avi } \\
\text { Public } \\
\text { ations }\end{array}$ & $\begin{array}{r}\text { Blac } \\
\mathrm{k} \text { and } \\
\text { Whit } \\
\mathrm{e}\end{array}$ & & $\begin{array}{l}\text { Sadegh } \\
\text { Sandog } \\
\text { hi }\end{array}$ & $\begin{array}{l}\text { Mehdi } \\
\text { Mashaye } \\
\text { khi }\end{array}$ & $\begin{array}{l}\text { Waiting } \\
\text { for } \\
\text { martyrd } \\
\text { om }\end{array}$ & 8 \\
\hline & & $*$ & & & & & & 15 & $\begin{array}{l}\text { Sarir } \\
\text { Public } \\
\text { ation }\end{array}$ & $\begin{array}{r}\text { Color } \\
\text { ed }\end{array}$ & $\begin{array}{l}\text { "A", } \\
\text { "B" }\end{array}$ & $\begin{array}{l}\text { A.li } \\
\text { Khoday } \\
\text { i }\end{array}$ & $\begin{array}{l}\text { Jafar } \\
\text { Ebrahimi } \\
\text { (Shahed) }\end{array}$ & $\begin{array}{l}\text { Wooden } \\
\text { barricad } \\
\text { es }\end{array}$ & 9 \\
\hline$*$ & & & & & & $*$ & $*$ & 22 & $\begin{array}{l}\text { Artisti } \\
\text { c } \\
\text { Center } \\
\text { of ads } \\
\text { organi } \\
\text { zation }\end{array}$ & $\begin{array}{r}\text { Color } \\
\text { ed }\end{array}$ & $\begin{array}{l}\text { "B", } \\
\text { "C" }\end{array}$ & $\begin{array}{l}\text { Khasha } \\
\text { yar } \\
\text { Ghaziza } \\
\text { deh }\end{array}$ & $\begin{array}{l}\text { Morteza } \\
\text { Sarhangi }\end{array}$ & $\begin{array}{l}\text { My } \\
\text { name, } \\
\text { Chaffiy } \\
\text { eh }\end{array}$ & 10 \\
\hline & & & & & & $*$ & & 8 & $\begin{array}{l}\text { Congr } \\
\text { ess } \\
\text { comm } \\
\text { emora } \\
\text { ting } \\
\text { the } \\
\text { martyr } \\
\text { comm } \\
\text { anders } \\
\text { of } \\
\text { Khora } \\
\text { san } \\
\text { provin } \\
\text { ce }\end{array}$ & $\begin{array}{r}\text { Color } \\
\text { ed }\end{array}$ & $\begin{array}{l}\text { "A", } \\
\text { "B", } \\
\text { "C" }\end{array}$ & $\begin{array}{l}\text { Illustrat } \\
\text { ors }\end{array}$ & $\begin{array}{l}\text { Group of } \\
\text { Writers }\end{array}$ & $\begin{array}{l}\text { Amateu } \\
\text { r RPG } \\
\text { perform } \\
\text { er }\end{array}$ & 11 \\
\hline & & $*$ & $*$ & & & & $*$ & 28 & $\begin{array}{l}\text { Shoko } \\
\text { ofeh } \\
\text { Books }\end{array}$ & $\begin{array}{r}\text { Color } \\
\text { ed }\end{array}$ & $\begin{array}{l}\text { "C", } \\
\text { "D" }\end{array}$ & $\begin{array}{l}\text { Siavash } \\
\text { Zolfaqa } \\
\text { rian }\end{array}$ & $\begin{array}{l}\text { Poetry } \\
\text { collection }\end{array}$ & $\begin{array}{l}\text { Flowers } \\
\text { mirrors, }\end{array}$ & 12 \\
\hline
\end{tabular}




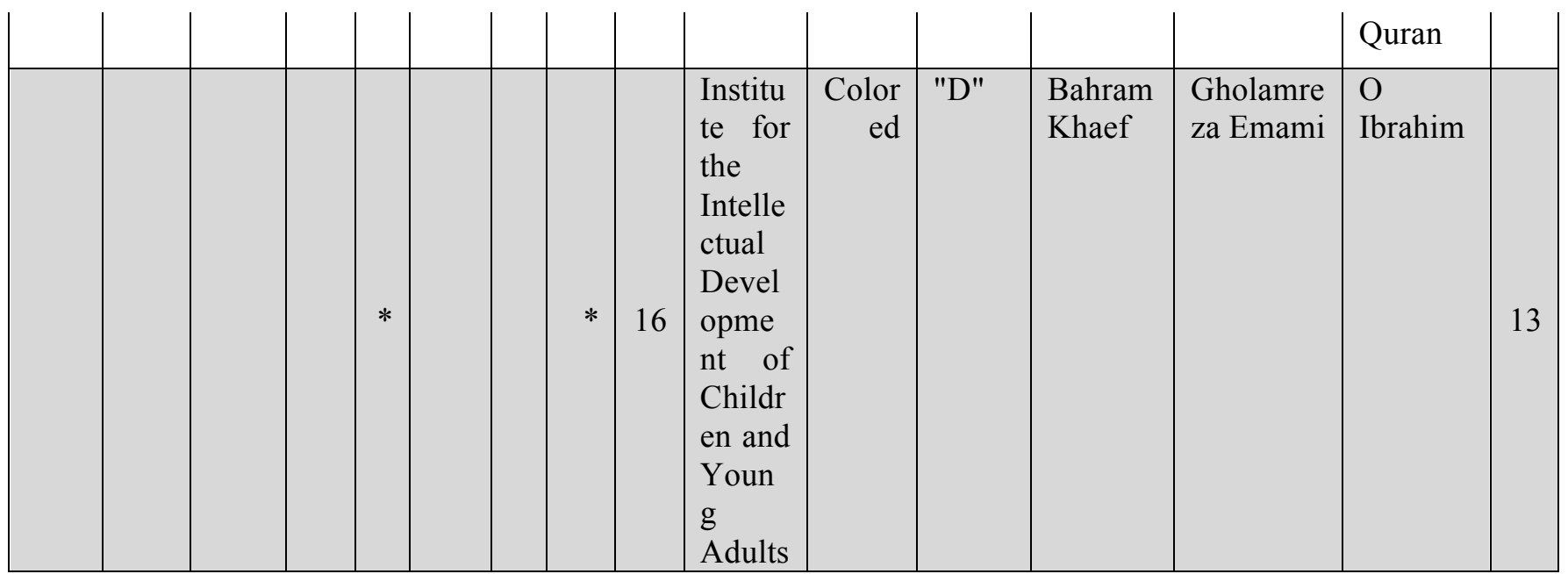

Table2. Reviewing Children's books about holy defense issue between the decades of 1980 s to 2010 s in Iran

\section{Source: author}

\section{CONCLUSION}

As Aristotle stated: "without picture, thinking is impossible"

Never prior knowing the audience, Illustrations begins. Knowing your audience is crucial in delivering a successful illustration. Illustration success lies in the nature of the message and the art of conveying a message.

Therefore, methods and tools that can be used to convey the message to the audience help interpretation and understanding of the subject of the story so much.

Illustrations for each age group should be proportionate to knowledge of the children at that age, because the psychological needs of children at different ages are various. In choosing this topic for illustrated books, it should be noted that audiences in which age group and the subject should be illustrated by efficient and attractive technique to according to the psychological needs of children.

Thus, the findings and conclusions of this paper are as follows:

In many illustrated books reviewed in this study between the decades of the 1980s to 2010s using analog methods and watercolor techniques, delivers the message to the audience well, but on the other hand part of the book illustrated with digital methods have not been successful in achieving their goals.

One of the reasons is its inability to implement analog and digital methods of illustrators to convey the message to the audience the story, i.e. the child.

In these cases, 8 cases was considered using analog methods and techniques of watercolor as having special executive features among artists rather than other techniques and creating imaginative style, emotional and subtle spaces as special feature of childhood and three carried out samples have been investigated by digital techniques.

Special features of the illustrated books are provided in a summary table. 
In Table 2 by presenting the issue of holy defense image books containing martyrdom, veterans and prisoner etc. and employed techniques, i.e. the most important cases including watercolor, crayon, Akolin, metal pen and digital techniques and then bringing up the coordination of images (techniques) with text and coordination between images and audience, but part of the books have not been successful.

\section{REFERENCES}

" Swing producer for children between fantasy and reality ', Royesh, Volume III, Issue 6, October 28, 1993

17 articles of children's literature, Children's Book Council, Masoomeh Sohrab (Mafi), 1993

Ebrahimi, Nader, "Introduction to visualization of children's books", first edition, Agah publishing, Tehran, 1988

Abolghasem Sayyed Sadr Encyclopedia of Arts, Tehran, Danesh publishing, 2004, First Edition Bakshi, Ali; "Digital Imaging", Tehran University, Faculty of Fine Arts, Expert in graphic design, 2000

Patricia Siansiolo, Zamani, Fatemeh. "Illustrations variations in children's books", Monthly book of children, issue 50, (December, 21 2001): pages 75-73.

Sarshar (Rahgozar), Mohammad Reza, "in the path of Hurricane, reviewing twenty years of Sacred Defense literature for children and adolescents", the message of freedom, 2004

Alireza Golduvzian, "Iranian illustrators year", Royesh 3, Society of Illustrators of children's books, internal magazine, winter 2005, page 15

Amid Hasan Amid Persian Dictionary

Fahimeh Pahlavan, "An Introduction to visual elements in logo", University of Art, Tehran 2002

Interview of Walter Crane with Maurice Sendak, "empty spaces in the text", translated by Zohreh Ghayini, children's literature Journal, Summer, 1997

Nami, Gholam Hossein, "Drawing with pen and ink", Tehran: Toos, 1987.

Hodayi, Mohammad, "picture books: children's literature and readings at preschool", Royesh, Number 22 October 26, 1989 